\title{
OBSERVATIONS ON THE METABOLISM OF POTASSIUM FROM A STUDY OF THE RENAL CLEARANCE
}

\author{
BY
}

\author{
H. ELLIS C. WILSON, M.B., Ch.B., D.Sc., F.R.F.P. and S.(Glas.) \\ (From the Department of Child Health, Glasgow University, and the Biochemical Department, \\ Royal Hospital for Sick Children, Yorkhill, Glasgow)
}

The object of the investigations recorded here was to obtain further information about the metabolism of potassium with particular reference to its rate of excretion in relation to the plasma level and to its retention, if any, by the tissues. The rôle played by potassium in the regulation of the water balance has been attracting an increasing amount of attention in recent years. It has been shown, for example, that in dehydrated infants with diarrhoea there is an excessive loss of potassium by the bowel (Butler et al., 1933). Recently, Darrow (1946) has recommended the use of a transfusion fluid for intravenous use which contains a relatively high concentration of potassium in order to replace this loss. By this means he aims at the restoration of intracellular water and salts as well as extracellular fluid. The potassium is held in the body mainly within the cells, while sodium is under normal conditions mostly without the cell-that is, in the plasma and other extracellular fluids.

Certain metabolites such as chloride are classified as threshold substances. When the concentration of such a metabolite in the blood reaches a certain level it is excreted in increasing degrees as the level rises. Such a correlation for potassium has not been found. McCance and Young (1941) estimated potassium clearances in infants and adults and noted that 'individual idiosyncrasies of which we have no certain knowledge far outweigh the influence of absolute serum levels on the clearance.' These workers showed that in adults the clearance tended to increase with the minute volume of urine secreted, while in the infants, where the urine flow was much less, this did not occur. They were unable to show any relation between the plasma level of potassium and its excretion in the urine.

\section{Present Investigation}

The following investigations were made in an attempt to determine the relationship between the level of potassium in the serum and its clearance by the kidney as well as its retention by the body. With one exception (a healthy adult) all the subjects were children in hospital and not suffering from any apparent acute infection or disease.

The children selected were all between seven and twelve years of age. The adult was a normal healthy male. In the case of the children a twohours' specimen of urine was collected and venous blood drawn off in the middle of the period, one sample in oxalate under oil for plasma chloride estimation, the other clotted for serum potassium. In all, fifty potassium clearances were estimated, thirty-eight without and twelve after giving $\mathbf{3 0}$ grains of potassium citrate. All the investigations were carried out at least two hours after a meal. Potassium clearances are expressed as $\mathrm{ml}$. per minute per square metre.

Chemical methods. Serum potassium was estimated by the cobaltinitrite method of Breh and Gaebler as modified by Hawk and Bergeim (1938). Where plasma potassium curves were done on the adult the micro-modification of Truszkowski and Zwemer (1937) was used. For this purpose, capillary blood was collected in heparin. Plasma chloride was estimated by Patterson's modification of the open Carius method as described by Peters and Van Slyke (1931) and fixed base by the benzidine sulphate method (Peters and Van Slyke, 1931). The potassium in urine was carried out on the phosphate-free solution used for total base estimation. Sodium in urine was calculated by the difference between fixed base and potassium. Volhard's method was used for determining chlorides in urine.

Observations on children. In order to show the difference in the behaviour of potassium excretion to that of chloride, observations of renal clearance in infants are graphed against the plasma levels (fig. 1a). Normally the chloride clearance tends to rise with an increase in its concentration in the plasma. In contrast, the potassium clearances (figs. $1 \mathrm{~b}$ and c) show a different trend both before and after giving potassium citrate. The lines show that in both sets of observations, the clearance of potassium rises as the serum level falls. It will be seen that the average plasma potassium after citrate, $20.4 \mathrm{mg}$., is actually lower than without, $21.8 \mathrm{mg}$. (marked $\mathrm{x}$ in figs. 1a and $\mathrm{b}$ ), although the difference, $1.4 \mathrm{mg}$., is just short of being statistically significant. 


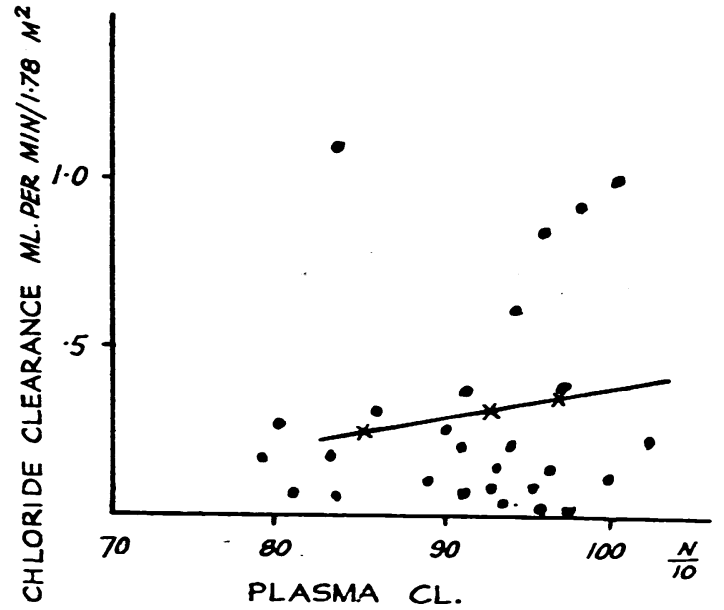

A.

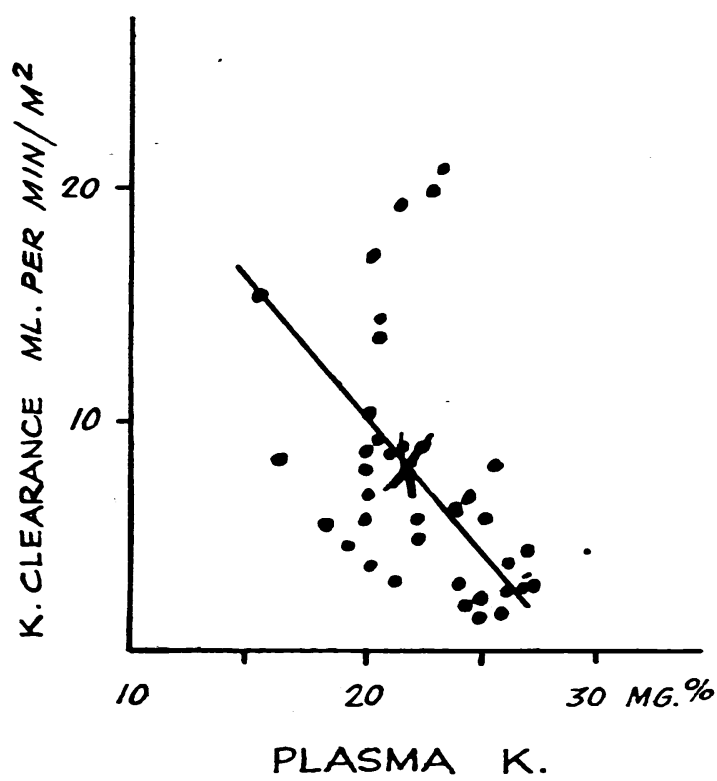

B.

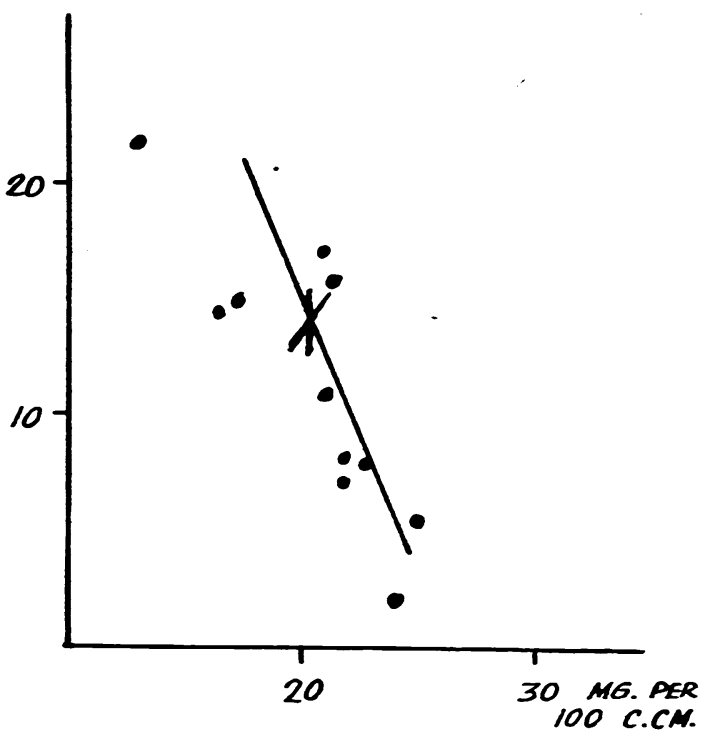

PLASMA K.

Fig. 1.

Fig. 1a.-Graph showing the relation between the plasma chloride level and the renal clearance in infants.

Figs. 1b and c.-Graphs showing the relation between the plasma potassium level and the renal clearance in children without and after the administration of potassium citrate. 


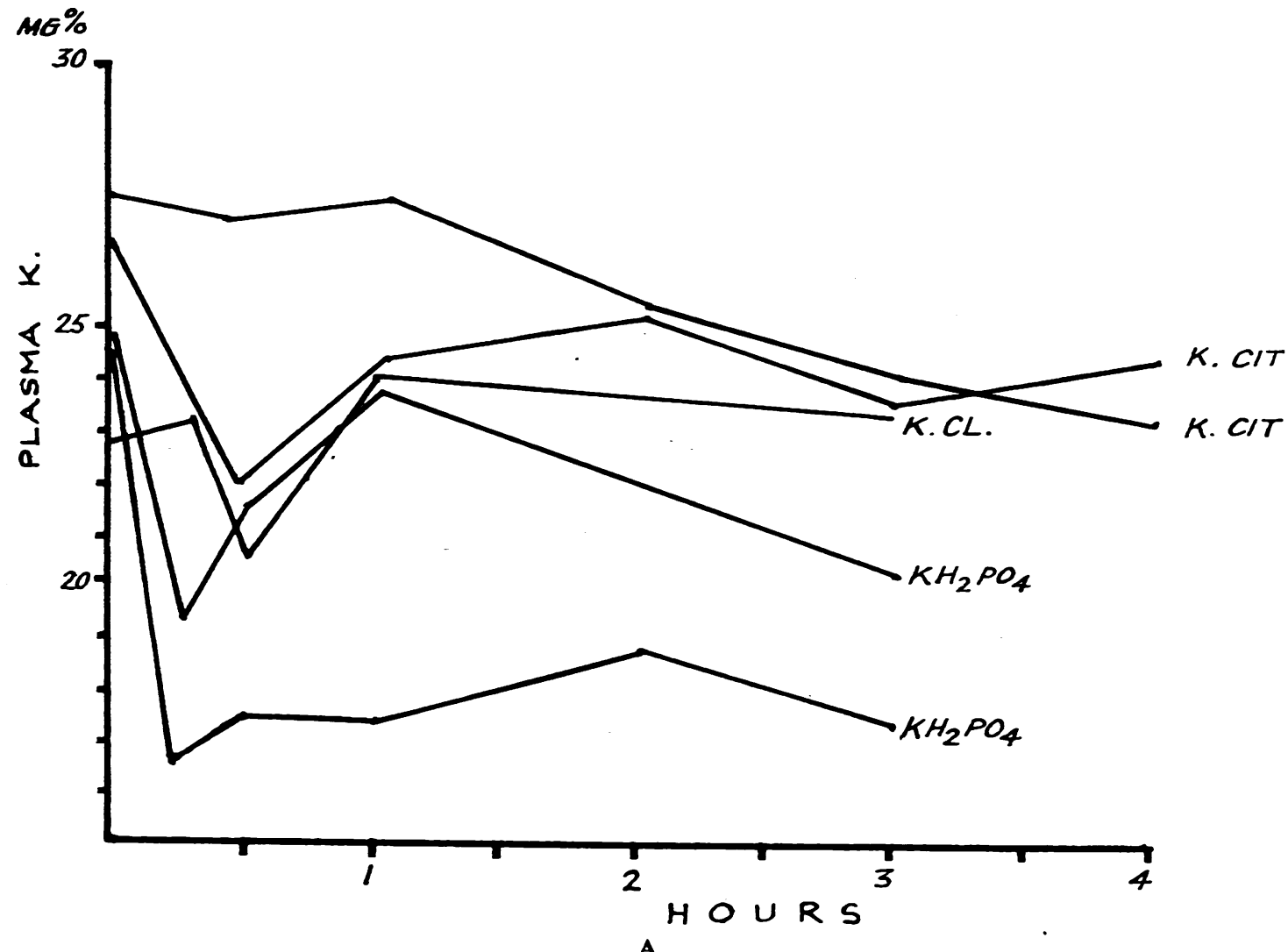

Fig. 2a.-Graph showing the plasma level of potassium at intervals after the ingestion of different potassium salts

This graph indicates that potassium cannot be considered as a threshold substance in the same sense as chloride. Some factor or factors other than the plasma level is obviously involved in the excretion of potassium. If this inverse relation between plasma level and excretion is true, the corollary might be drawn that after taking a potassium salt by mouth the blood level should fall, as this ion is known to be quickly excreted. In order to test this suggestion plasma potassium curves were carried out on an adult after taking potassium salts.

Potassium curves on plasma. Three salts of potassium were employed, namely, the acid phosphate $\left(\mathrm{KH}_{2} \mathrm{PO}_{3}\right)$, the chloride $(\mathrm{KCl})$ and the citrate $\left(\mathrm{C}_{6} \mathrm{H}_{6} \mathrm{O}_{7} \mathrm{~K}_{3}\right)$, an organic salt. The amount of potassium taken as such in each case was approximately one gramme, except that on one occasion three grammes were taken as the citrate salt. No ill effects were noted. The salts were dissolved in $200 \mathrm{ml}$. water and taken by mouth.

The effect of the ingestion of potassium salts on the plasma level, the urinary output of sodium chloride, and the potassium clearance are seen in tables 1 to 5 .

In calculating the potassium clearances, the figures for the plasma potassium used were the averages at the beginning and end of each hour period, except in the pre-period, when the initial figure was used, and in period I, where the values of the intervening 15 - or 30 -minute intervals were incorporated. The excess outputs of potassium sodium and chloride excreted in the four hours have been calculated by subtracting their excretion in the pre-period, that is, before potassium ingestion, from each succeeding hourly period and adding the total. Those figures and the plasma potassium curves are appended below each separate set of observations (tables 1 to 5 ).

The behaviour of the plasma potassium and its relation to the clearance are more clearly seen from the graphs (fig. 2). The plasma curve fell after giving $1 \mathrm{~g}$. of potassium by mouth, except in the case of the chloride salt where the level remained almost constant. The progressive rise in the clearance accompanied by $a$ fall in the plasma potassium 


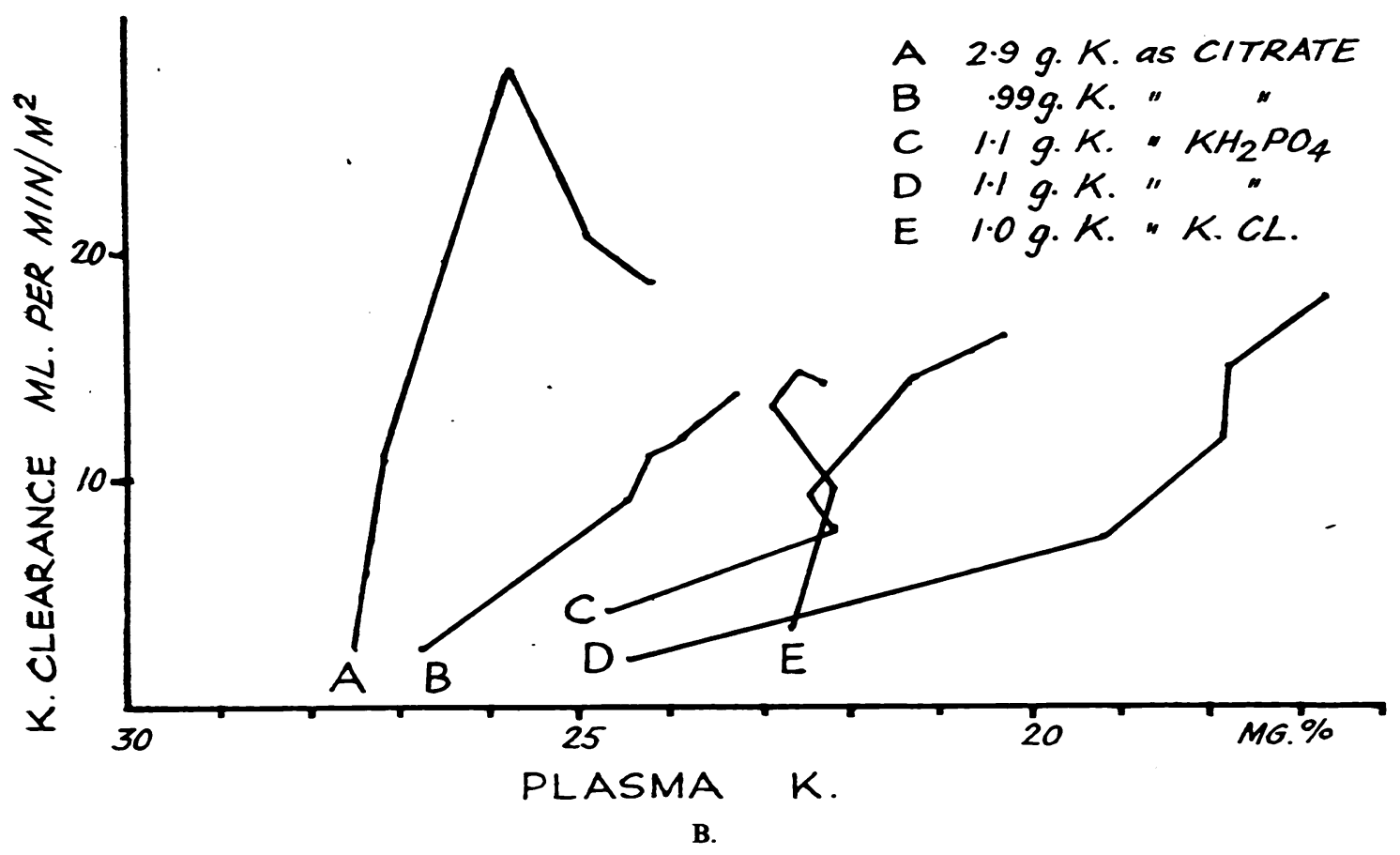

Fig. 2b.-Graph showing the progressive rise in clearance and fall in plasma potassium after ingestion of potassium salts.

after the phosphate and citrate are illustrated in fig. $2 b$.

\section{Discussion}

It would appear that the excretion of potassium is not determined primarily by the plasma level and that hence it cannot be considered a true threshold substance in the sense that it is excreted when the concentration in the blood rises above a certain level. Two questions must therefore be considered:

(a) What is the explanation of the fall in the plasma level after taking a potassium salt by mouth?

(b) What determines the rate of excretion of potassium ?

The fall in the plasma level before all the ingested material has been excreted would suggest that some tissue or tissues are actively taking up the ion. Winkler and Smith (1938) showed that in dogs, after intravenous injection of potassium as the bromide, chloride, or phosphate, there was a temporary rise in the plasma potassium level. They observed also that some time after the injection had been stopped, and when a considerable amount of potassium had been excreted, the plasma level tended to rise still further. They concluded that the tissue cells had initially taken up the ion and later discharged it into the plasma. They corroborated this assumption by estimating the concentration
TABLE 1

\begin{tabular}{|c|c|c|c|c|}
\hline & & $\begin{array}{l}\text { K clear- } \\
\text { ance ml. } \\
\text { per } \\
\mathrm{min} / \mathrm{m}_{2}\end{array}$ & $\begin{array}{c}\text { Na out- } \\
\text { put } \\
\text { (fixed } \\
\text { base-K) } \\
\text { N/10 per } \\
\text { hour }\end{array}$ & $\begin{array}{c}\text { Cl out- } \\
\text { put } \\
\text { N/10 per } \\
\text { hour }\end{array}$ \\
\hline Pre-period & \multirow{5}{*}{$\begin{array}{l}1 \text { hour before } \\
1 \cdot 14 \mathrm{~g} \text { K as } \\
\mathrm{KH}_{2} \mathrm{PO} \\
1 \text { hour after } \\
\mathrm{K} \text { phosphate } \\
2 \text { hours after } \\
\mathrm{K} \text { phosphate } \\
3 \text { hours after } \\
\mathrm{K} \text { phosphate } \\
4 \text { hours after } \\
\mathrm{K} \text { phosphate }\end{array}$} & $4 \cdot 0$ & $17 \cdot 7$ & $26 \cdot 8$ \\
\hline \multirow{4}{*}{$\begin{array}{l}\text { Period I } \\
\text { Period II } \\
\text { Period III } \\
\text { Period IV }\end{array}$} & & $7 \cdot 2$ & $45 \cdot 9$ & $53 \cdot 7$ \\
\hline & & $9 \cdot 1$ & $78 \cdot 4$ & $89 \cdot 8$ \\
\hline & & $16 \cdot 7$ & $118 \cdot 3$ & $127 \cdot 7$ \\
\hline & & & $90 \cdot 5$ & $83 \cdot 0$ \\
\hline
\end{tabular}

Per cent. of ingested $\mathrm{K}$ excreted in 4 hours $(145 \mathrm{ml} . \mathrm{N} / 10)$ $=49 \cdot 5$.

Excess $\mathrm{Na}$ excreted in 4 hours $=262 \cdot 3 \mathrm{ml}$. N/10.

Excess Cl excreted in 4 hours $=247 \cdot 1 \mathrm{ml}$. N/10.

Per cent. $K$ retained at end of 4 hours $(144 \mathrm{ml}$. N/10) $=50 \cdot 5$.

Plasma K levels: 0 mins., 24.9; 15 mins., 19.3; 30 mins., $21 \cdot 1 ; 1 \mathrm{hr}$., $23 \cdot 6$; 2 hrs., $22 \cdot 1 ; 3 \mathrm{hrs}$., $20 \cdot 3$. 
TABLE 2

\begin{tabular}{|c|c|c|c|c|}
\hline & & $\begin{array}{l}\text { K clear- } \\
\text { ance ml. } \\
\text { per } \\
\mathrm{min} / \mathrm{m}_{2}\end{array}$ & $\begin{array}{l}\text { Na out- } \\
\text { put } \\
\text { (fixed } \\
\text { base-K) } \\
\text { N/10 per } \\
\text { hour }\end{array}$ & $\begin{array}{l}\text { Cl out- } \\
\text { put } \\
\text { N/10 per } \\
\text { hour }\end{array}$ \\
\hline Pre-period & $\begin{array}{l}1 \text { hour before } \\
1 \cdot 14 \mathrm{~g} \text {. K as } \\
\mathrm{KH}_{2} \mathrm{PO}_{4}+ \\
300 \mathrm{c} \text {. extra } \\
\mathrm{H}_{2} \mathrm{O}\end{array}$ & $2 \cdot 82$ & $28 \cdot 8$ & $30 \cdot 1$ \\
\hline Period I & $\begin{array}{l}1 \text { hour after } \\
\mathrm{K} \text { phosphate }\end{array}$ & $7 \cdot 67$ & $85 \cdot 3$ & $94 \cdot 1$ \\
\hline \multirow{2}{*}{$\begin{array}{l}\text { Period II } \\
\text { Period III }\end{array}$} & $\begin{array}{l}2 \text { hours after } \\
\mathbf{K} \text { phosphate }\end{array}$ & $12 \cdot 67$ & $90 \cdot 7$ & $134 \cdot 4$ \\
\hline & $\begin{array}{l}3 \text { hours after } \\
\mathbf{K} \text { phosphate }\end{array}$ & $14 \cdot 64$ & $93 \cdot 3$ & $151 \cdot 1$ \\
\hline Period IV & K phosphate & $19 \cdot 5$ & $34 \cdot 0$ & $112 \cdot 3$ \\
\hline
\end{tabular}

Per cent. of ingested $\mathrm{K}$ excreted in 4 hours $(154 \cdot 1 \mathrm{ml}$. $\mathrm{N} / 10)=52 \cdot 7$.

Excess $\mathrm{Na}$ excreted in 4 hours $=189 \cdot 1 \mathrm{ml}$. $\mathrm{N} / 10$.

Excess $\mathrm{Cl}$ excreted in 4 hours $=371.5 \mathrm{ml}$. N/10.

Per cent. $K$ retained at end of 4 hours $(138 \mathrm{ml}$. $\mathrm{N} / 10)$ $=47 \cdot 3$.

Plasma K levels: 0 mins., 24 -6; 15 mins., 16 5 ; 30 mins., 17.4; 1 hr., 17.4; 2 hrs., 18.7 ; 3 hrs., 17.3.

TABLE 3

\begin{tabular}{|c|c|c|c|c|}
\hline & & $\begin{array}{c}\text { K clear- } \\
\text { ance ml. } \\
\text { per } \\
\mathrm{min} / \mathbf{m}_{2}\end{array}$ & $\begin{array}{c}\text { Na out- } \\
\text { put } \\
\text { (fixed } \\
\text { base-K) } \\
\text { N/10 per } \\
\text { hour }\end{array}$ & $\begin{array}{l}\text { Cl out- } \\
\text { put } \\
\text { N/10 per } \\
\text { hour }\end{array}$ \\
\hline Pre-period & $\begin{array}{l}1 \text { hour before } \\
1.05 \mathrm{~g} . \mathrm{K} \text { as } \\
\mathrm{KCl}\end{array}$ & $3 \cdot 58$ & $17 \cdot 58$ & $21 \cdot 6$ \\
\hline Period I & 1 hour after & $10 \cdot 20$ & $62 \cdot 40$ & 87.0 \\
\hline Period II & 2 hours after & $11 \cdot 60$ & $70 \cdot 90$ & $114 \cdot 2$ \\
\hline & $\begin{array}{l}3 \text { hours after } \\
\text { K chloride }\end{array}$ & $12 \cdot 70$ & $92 \cdot 30$ & $140 \cdot 0$ \\
\hline Period IV & $\begin{array}{l}4 \text { hours after } \\
\mathrm{K} \text { chloride }\end{array}$ & $12 \cdot 00$ & $79 \cdot 20$ & $81 \cdot 7$ \\
\hline
\end{tabular}

Per cent. of ingested $\mathrm{K}$ excreted in 4 hours $(174 \mathrm{ml} . \mathrm{N} / 10)$ $=64 \cdot 6$.

Excess $\mathrm{Na}$ excreted in 4 hours $=234.8 \mathrm{ml}$. N/10.

Excess $\mathrm{Cl}$ excreted in 4 hours $=336.5 \mathrm{ml}$. $\mathrm{N} / 10$.

Per cent. $K$ retained at end of 4 hours (109 ml. N/10) $=35 \cdot 4$.

Plasma K levels: 0 mins., 22.9; 15 mins., 23 $\cdot 2$; 30 mins., $20 \cdot 4$; 1 hr., 23.8; 2 hrs., 23.8; 3 hrs., $23 \cdot 4$.
TABLE 4

\begin{tabular}{|c|c|c|c|c|}
\hline - & & $\begin{array}{l}\text { K clear- } \\
\text { ance ml. } \\
\text { per } \\
\text { min } / \mathbf{m}_{2}\end{array}$ & $\begin{array}{c}\text { Na out- } \\
\text { put } \\
\text { (fixed } \\
\text { base-K) } \\
\text { N/10 per } \\
\text { hour }\end{array}$ & $\begin{array}{l}\text { Cl out- } \\
\text { put } \\
\text { N/10 per } \\
\text { hour }\end{array}$ \\
\hline Pre-period & $\begin{array}{l}1 \text { hour before } \\
0.99 \mathrm{~g} . \mathrm{K} \text { as } \\
\text { citrate }\end{array}$ & $2 \cdot 11$ & $21 \cdot 5$ & $24 \cdot 1$ \\
\hline Period I & $\begin{array}{l}1 \text { hour after } \\
K \text { citrate }\end{array}$ & $9 \cdot 50$ & $74 \cdot 4$ & $64 \cdot 4$ \\
\hline Period II & $\begin{array}{l}2 \text { hours after } \\
\mathbf{K} \text { citrate }\end{array}$ & $10 \cdot 10$ & $100 \cdot 4$ & $100 \cdot 7$ \\
\hline Period III & $\begin{array}{l}3 \text { hours after } \\
\mathbf{K} \text { citrate }\end{array}$ & $10 \cdot 60$ & $106 \cdot 4$ & $116 \cdot 1$ \\
\hline Period IV & $\begin{array}{l}4 \text { hours after } \\
K \text { citrate }\end{array}$ & $12 \cdot 70$ & $81 \cdot 5$ & $102 \cdot 9$ \\
\hline
\end{tabular}

Per cent. of ingested $\mathrm{K}$ excreted in 4 hours $(175 \mathrm{ml} . \mathrm{N} / 10)$ $=69 \cdot 1$.

Excess $\mathrm{Na}$ excreted in 4 hours $=276.7 \mathrm{ml}$. $\mathrm{N} / 10$.

Excess Cl excreted in 4 hours $=307.7 \mathrm{ml}$. N/10.

Per cent. $K$ retained at end of 4 hours $(87.7 \mathrm{ml}$. N/10) $=30 \cdot 1$.

Plasma K levels: 0 mins., 26.9; 30 mins., 22.8; $1 \mathrm{hr}$,

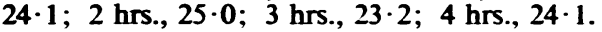

TABLE 5

\begin{tabular}{|c|c|c|c|c|}
\hline & & $\begin{array}{l}\text { K clear- } \\
\text { ance ml. } \\
\text { per } \\
\mathrm{min} / \mathrm{m}_{2}\end{array}$ & $\begin{array}{c}\text { Na out- } \\
\text { put } \\
\text { (fixed } \\
\text { base-K) } \\
\text { N/10 per } \\
\text { hour }\end{array}$ & $\begin{array}{l}\text { Cl out- } \\
\text { put } \\
\mathrm{N} / 10 \text { per } \\
\text { hour }\end{array}$ \\
\hline Pre-period & $\begin{array}{l}1 \text { hour before } \\
2.96 \mathrm{~g} . \mathrm{K} \text { as } \\
\text { citrate }\end{array}$ & $3 \cdot 01$ & & $21 \cdot 9$ \\
\hline Period I & $\begin{array}{l}1 \text { hour after } \\
K \text { citrate }\end{array}$ & .90 & $106 \cdot 6$ & $\begin{array}{l}21 \cdot 9 \\
79 \cdot 8\end{array}$ \\
\hline Period II & 2 hours after & $28 \cdot 50$ & $184 \cdot 0$ & $180 \cdot 1$ \\
\hline Period III & $\begin{array}{l}3 \text { hours after } \\
\mathbf{K} \text { citrate }\end{array}$ & $20 \cdot 10$ & $153 \cdot 0$ & $148 \cdot 3$ \\
\hline Period IV & $\begin{array}{l}4 \text { hours after } \\
\text { Kcitrate }\end{array}$ & $19 \cdot 80$ & $158 \cdot 8$ & $144 \cdot 9$ \\
\hline
\end{tabular}

Per cent. of ingested $\mathrm{K}$ excreted in 4 hours $(459 \mathrm{ml}$. N/10) $=69 \cdot 1$.

Excess $\mathrm{Na}$ excreted in 4 hours $=374.0 \mathrm{ml}$. N/10.

Excess $\mathrm{Cl}$ excreted in 4 hours $=475.5 \mathrm{ml}$. N/10

Per cent. K retained at end of 4 hours $(299.0 \mathrm{ml}$. N/10) $=30 \cdot 9$.

Plasma K levels: 0 mins., 27-5: 30 mins., 27-2; $1 \mathrm{hr}$., $27 \cdot 7 ; 2$ hrs., $25 \cdot 5 ; 3$ hrs., $24 \cdot 4 ; 4$ hrs., $23 \cdot 2$. 
both of potassium and of bromide in the plasma after the intravenous injection of potassium bromide: The bromide appeared to have been distributed in the extracellular fluid only, while the potassium had been more widely distributed. They concluded that after the injection of potassium salts the tissue cells take up this ion temporarily, and later discharge it into the blood. Whether potassium entered the cells by passive diffusion or by some process of active absorption could not be decided. Larson (1940) showed that after epinephrine injections the plasma potassium rises due to potassium freed from the liver. This rise is quickly followed by a fall to below the initial level. He showed that the muscles and particularly the liver were responsible for this rapid withdrawal of potassium from the blood. Stickney (1941), working with frogs, found a similar rise followed by a fall below the initial level of plasma potassium after epinephrine injections. The evidence in general appears to show that muscle and particularly liver cells readily absorb potassium from the plasma even to the extent of bringing the plasma level below the initial figure. These facts, however, would not entirely account for the fall in level and increased excretion found after oral administration. The increased clearance following oral administration might be explained on the assumption that it is not the plasma level but the degree of saturation of the liver and/or tissue cells which is the controlling factor in the excretion of potassium.

The hypothesis is therefore put forward that after oral administration the liver is quickly saturated with potassium and the kidney stimulated by some hormone or secretion to promote potassium elimination. If the rate of elimination were greater than the discharge by the liver the plasma level would fall. Cortin or one of its derivatives naturally suggests itself as the effective agent controlling the rate of excretion of potassium. In suprarenal deficiency for example, there is a retention of potassium and a rise in the plasma level. Administration of cortin leads to an increased elimination and a fall in plasma potassium. This effect of cortin is also associated with a retention of sodium chloride. In the observations recorded here, however, the increased elimination of potassium is associated with the usual increased output of sodium. This point will be discussed later.

The evidence presented so far would suggest that the excretion of potassium by the kidney is not controlled directly by the plasma level but that the concentration in the body and/or liver cells is the controlling factor. This point is worth considering when the conception of renal function tends to centre largely on its rôle as controller of the composition of the extracellular fluids. As the total potassium of the body is present mostly in the cells the mechanism proposed here would appear to be biologically useful.

Two facts emerge from this investigation:

1. The fall in the plasma level of potassium is more marked with the phosphate and scarcely noted with the chloride salt.

2. The known fact that after potassium ingestion there is an increased output of sodium and chloride in the urine.

The fall in the plasma level after the phosphate and its absence after the chloride would appear to indicate that the former is more readily taken up by the tissues than the latter, although the excess amount excreted in the four hours is approximately the same. The phosphate and the chloride differ physiologically in that the chlorine ion is an alien in the cells. It is possible that after the administration of potassium chloride the chlorine ion exerts a restraining influence on the potassium from entering the cells, and hence the fall in plasma level in the blood is not noted The difference in the behaviour of the two salts may be of practical importance in connexion with the composition of solutions used for continuous intravenous infusion in dehydrated infants. The usual intravenous solution contains sodium chloride as the main mineral salt. As such it is suited to replace the loss of extracellular fluid and electrolyte. Butler et al. (1933) showed, however, that in gastro-enteritis there is an excess loss of potassium in the stools. This loss is more than could be accounted for by the associated breakdown of body tissue as estimated by the nitrogen output. It appeared then that in gastro-enteritis the cells were being both dehydrated and impoverished of potassium. Darrow (1946) employed fluids containing potassium chloride in concentration higher than Hartman's solution in order to replace this loss. It is suggested from the observations recorded here that possibly the phosphate rather than the chloride might prove the more effective salt for intravenous transfusion. Darrow (1946) also observed that after the transfusion had been commenced there was a potassium retention and a loss of sodium, which according to his calculations, must have come not from the extracellular fluids, but from the cells. This raises the question of the source of the excess sodium output after potassium has been taken by mouth. Two possible sources for the excess sodium may be considered, namely, the extracellular fluids and the cells. Normally the cells contain little or no sodium. Miller and Darrow (1940) showed that in rats fed on diets low in potassium the concentration of this ion fell in the muscles and was replaced up to a point by sodium. They found that approximately one millimoll of sodium replaced two millimolls of potassium. On giving potassium the sodium was eliminated. In the experiments recorded here there was a considerable excess of sodium excreted in four hours in comparison with the potassium retention at the same time. In experiments $a$ and $b$ (tables 1 to 5), for instance, the excess sodium excreted in four hours was $262 \cdot 3$ and $189 \cdot 1$ millimolls respectively, while the potassium retained in the same period was 144 and 138 millimolls respectively. The excess output of sodium in 
relation to potassium retained at the end of four hours is hence far above the ratio found by Miller and Darrow, namely, one millimoll of sodium displaced by two of potassium. It would appear that this excess of sodium, or at least most of it, cannot have come from within the cells. This excess sodium, moreover, is associated with a corresponding elimination of chloride-an extracellular electrolyte. Hence it can be concluded that the diuretic effect of potassium salts in the human subject is to drive out extracellular salts such as sodium chloride. The cause of this increased elimination of sodium chloride during a potassium diuresis may be due to a diminished reabsorption of salt in the renal tubules, the process of tubular reabsorption being hindered by the increased concentration of potassium ions undergoing excretion. If however, cortin is the effective agent stimulating the kidney to excrete potassium, one would expect-on an analogy with its effect in treating Addison's disease-that the sodium chloride excretion would be decreased. This question hence awaits further investigation.

\section{Conchusions}

1. Observations on children with and without the administration of potassium citrate by mouth show that the potassium clearances tend to vary inversely with the plasma level.

2. In the adult the plasma potassium curve after potassium phosphate and citrate, but not after chloride, falls while the clearance rises. The conclusion is drawn that the main factor controlling the excretion of potassium is the saturation of the cells with this electrolyte.

3. There is evidence to show that potassium enters the cells more readily when given as the phosphate or citrate than as the chloride. The significance of this finding in relation to the composition of fluids for intravenous use in combating extracellular and intracellular dehydration is discussed.

I wish to thank Professor Stanley Graham for his help and advice in the preparation of this paper.

\section{ReFerences}

Butler, A. M., McKhann, C. F., and Gamble, J. L. (1933). J. Pediat., 3, 84.

Darrow, D. C. (1946). Ibid., $28,515$.

Hawk, P. B., and Bergeim, O. (1937). Practical Physiological Chemistry. 11th Edit. London. Churchill.

Larson, P. S. (1940). Amer. J. Physiol., 130, 562.

McCance, R. A., and Young, W. F. (1941). J. Physiol., 99, 265.

Milker, H. C., and Darrow, D. C. (1940). Amer. J. Physiol., 130, 747.

Peters, J. P., and Van Slyke, D. D. (1931). Quantitative Clinical Chemistry. Vols. 1 and 2. London. Baillière, Tindall and Cox.

Stickney, J. C. (1941). Amer. J. Physiol., 132, 11.

Truszkowski, R., and Zwemer, R. L. (1937). Biochem. J., 31, 229.

Winkler, A. W., and Smith, P. K. (1938). J. Biol. Chem., $124,589$. 